\title{
Comparative expression pattern of Matrix-Metalloproteinases in human glioblastoma cell-lines and primary cultures
}

Carsten Hagemann ${ }^{1 * \dagger}$, Jelena Anacker ${ }^{2 \dagger}$, Stefanie Haas $^{3}$, Daniela Riesner ${ }^{1}$, Beate Schömig ${ }^{1}$, Ralf-Ingo Ernestus ${ }^{1}$, Giles H Vince ${ }^{1}$

\begin{abstract}
Background: Glioblastomas (GBM), the most frequent malignant brain tumors in adults, are characterized by an aggressive local growth pattern and highly invasive tumor cells. This invasion is facilitated by expression of matrix metalloproteinases (MMPs), a family of zinc-dependent endopeptidases. They mediate the degradation of protein components of the extracellular matrix. Twenty-three family members are known. Elevated levels of several of them have been reported in GBM. GBM cell-lines are used for in vitro studies of cell migration and invasion. Therefore, it is essential to know their MMP expression patterns. Only limited data for some of the cell-lines are published, yet. To fill the gaps in our knowledge would help to choose suitable model systems for analysis of regulation and function of MMPs during GBM tumorigenesis, cell migration and invasion.

Findings: We analysed MMP-1, $-8,-9,-10,-11,-13,-17,-19,-20,-21,-23,-24,-26,-27$, and MMP-28 expression in seven GBM cell-lines (SNB-19, GaMG, U251, U87, U373, U343, U138) and in four primary cell cultures by semiquantitative RT-PCR, followed changes in the MMP expression pattern with increasing passages of cell culture and examined the influence of TNF- $\alpha$ and TGF- $\beta 1$ stimulation on the expression of selected MMPs in U251 and U373 cells.

MMP-13, $-17,-19$ and -24 were expressed by all analyzed cell-lines, whereas MMP-20 and MMP-21 were not expressed by any of them. The other MMPs showed variable expression, which was dependent on passage number. Primary cells displayed a similar MMP-expression pattern as the cell-lines. In U251 and U373 cells expression of MMP-9 and MMP-19 was stimulated by TNF- $\alpha$. MMP-1 mRNA expression was significantly increased in U373 cells, but not in U251 cells by this cytokine. Whereas TGF- $\beta 1$ had no impact on MMP expression in U251 cells, it significantly induced MMP-11 and MMP-24 expression in U373 cells.

Conclusions: Literature-data and our own results suggest that the expression pattern of MMPs is highly variable, dependent on the cell-line and the cell-culture conditions used and that also regulation of MMP expression by cytokines is cell-line dependent. This is of high impact for the transfer of cell-culture experiments to clinical implementation.
\end{abstract}

\section{Findings}

\section{Background}

Glioblastomas (GBM) are the most common malignant brain tumors in adults [1]. Patients have very limited prognosis due to the aggressive local growth pattern of

\footnotetext{
* Correspondence: hagemann_c@klinik.uni-wuerzburg.de

+ Contributed equally

'University of Würzburg, Department of Neurosurgery, Tumorbiology

Laboratory, Würzburg, Germany

Full list of author information is available at the end of the article
}

these tumors [2-4]. Invasion of tumor cells into the healthy brain tissue is facilitated by expression of different proteolytic enzymes like matrix metalloproteinases (MMPs), a family of zinc-dependent endopeptidases $[5,6]$. They mediate the degradation of protein components of the extracellular matrix [7]. To date, $23 \mathrm{mem}-$ bers of the human MMP gene family are known [8]. Elevated levels of several MMPs, like for example MMP-1, - 2, -7, -9, -11, -12,-14,-15,-19, -24 and -25 have been reported in malignant glioma samples from

\section{Biomed Central}


patients [6,9-20], suggesting that their expression is closely related to malignant progression in vivo.

Human GBM cell-lines are used for in vitro studies of cell migration and invasion [21-24] and numerous studies investigated expression of selected MMPs in human GBM cell-lines (Table 1) [10,15,19,20,25-36]. However, several MMPs have not been analysed in these cells, yet. Therefore, there are large gaps in our knowledge about MMP expression in human GBM cell-lines. To fill these gaps would help to choose suitable model systems for the analysis of regulation and function of MMPs during GBM tumorigenesis, cell migration and invasion.

In seven glioblastoma cell-lines (SNB-19, GaMG, U251, U87, U373, U343, U138) and in four primary cell cultures, established from tumor specimens analysed previously by our group [16], we performed a comprehensive study of MMP expression using semiquantitative RT-PCR. In addition, we followed changes in the MMP expression pattern with increasing passages of cell culture and we examined the influence of TNF- $\alpha$ and TGF- $\beta 1$ stimulation on the expression of selected MMPs in U251 and U373 cells.

\section{Expression of MMPs in glioblastoma cell-lines}

Expression of fifteen MMPs was analysed in the seven GBM cell-lines SNB-19, GaMG, U251, U87, U373, U343 and U138 by semiquantitative RT-PCR (Figure 1).
Those MMPs were examined with no or very limited data published about their expression in GBM cell-lines. No mRNA expression was detectable for MMP-8, -20, $-21,-26$ and MMP-27 (Figure 1). MMP-19 mRNA was strongly expressed in all analysed cell-lines, whereas MMP-10, -17 and -23 mRNAs were only very weakly detectable (Figure 1). The other surveyed MMPs showed a diverse expression in the different GBM cell-lines (Figure 1).

These results became more obvious after densitometric quantification (Figure 2). MMP-19 was highly expressed in U87, U343 and U138 cells (Figure 1, Figure 2). Whereas its expression remained stable for 15 passages in SNB-19, U373, U343 and U138 cells, there was a statistically significant decrease of MMP-19 mRNA expression at passage 15 in GaMG, U251 and U87 cells (Figure 2). MMP-1 mRNA expression was strongest in U87, U343 and U138 cells and remained stable for 15 passages. However, it was very weakly expressed in SNB-19 and U373 cells and the intermediate expression in GaMG and U251 cells was successively reduced with passaging of cells (Figure 2). A comparable reduction of mRNA expression was found for MMP-11 in GaMG and U251 cells, MMP-17 in GaMG cells and MMP-24 in SNB-19, GaMG, U251 and U87 cells (Figure 2). MMP-10 was not detectable in U87 cells, MMP-11 not in SNB-19, U87 and U373 cells,

Table 1 MMP expression in glioblastoma cell-lines

\begin{tabular}{|c|c|c|c|c|c|c|c|}
\hline & SNB-19 & GaMG & U251 & U87 & U373 & U343 & U138 \\
\hline MMP-1 & + & + & $t^{25,31,35}$ & $+/{ }^{15,28,35}$ & $t^{35}$ & $t^{25}$ & + \\
\hline MMP-2 & $++^{19,20}$ & $++^{19}$ & $+{ }^{19,20,25,26,31,35,36 /-^{33}}$ & $+^{10,15,28,33,35,36}$ & $++^{10,19,35,36}$ & -25 & $++^{19,36}$ \\
\hline MMP-3 & $++^{19}$ & -19 & $+^{19,31,6}$ & $++^{15,36 /-28}$ & $++^{36} /-^{19}$ & & $+{ }^{19} /-^{36}$ \\
\hline MMP-7 & $++^{19}$ & $-{ }^{19}$ & $+{ }^{19,26,31,35,36}$ & $++^{15,30} /-^{35}$ & $+{ }^{19,35,36}$ & & $+{ }^{636} /{ }^{19}$ \\
\hline MMP-8 & - & - & $++^{31} /-26$ & - & - & - & - \\
\hline MMP-9 & $++^{29,30} /-^{19}$ & $++^{19}$ & $+{ }^{19,31} /-^{25,36}$ & $+{ }^{10,15,36} /{ }^{28}$ & $++^{10,19} /{ }^{36}$ & -25 & ${ }^{-19,36}$ \\
\hline MMP-10 & + & + & $++^{26,31}$ & - & + & + & + \\
\hline MMP-11 & - & + & $++^{31} /-^{35}$ & -35 & $+35 /-$ & + & + \\
\hline MMP-12 & $++^{19}$ & $-{ }^{19}$ & $++^{19,31 /-^{36}}$ & $+^{36}$ & $-^{19,36}$ & & $+{ }^{19} /-^{36}$ \\
\hline MMP-13 & + & + & $+^{26,31}$ & + & + & + & + \\
\hline MMP-14 & $++^{20}$ & & $+^{20,26,31,34-36}$ & $++^{10,15,31,32,35,36 /-28}$ & $+{ }^{31,35,36} /{ }^{10}$ & $+^{31}$ & $+^{36}$ \\
\hline MMP-15 & & & $+^{31,34,35}$ & $++^{31,32 /-35}$ & $+{ }^{31} /-^{35}$ & $++^{31}$ & \\
\hline MMP-16 & & & $+{ }^{26,34} /-^{31,35}$ & $+^{31,32,35}$ & $-31,35$ & -31 & \\
\hline MMP-17 & + & + & $++^{31}$ & $++^{31}$ & $++^{31}$ & $++^{31}$ & + \\
\hline MMP-19 & + & + & $t^{31}$ & + & + & + & + \\
\hline MMP-20 & - & - & -31 & - & - & - & - \\
\hline MMP-21 & - & - & -31 & - & - & - & - \\
\hline MMP-23 & + & - & $+^{31}$ & + & + & + & + \\
\hline MMP-24 & + & + & $+^{31,34}$ & $t^{31}$ & $t^{31}$ & $t^{31}$ & + \\
\hline MMP-25 & & & -31 & -31 & -31 & -31 & \\
\hline MMP-26 & - & - & $++^{31} /-^{27}$ & - & - & - & - \\
\hline MMP-27 & - & - & $++^{31} /-$ & - & - & - & - \\
\hline MMP-28 & + & - & $t^{31}$ & - & + & + & - \\
\hline
\end{tabular}

+: expressed; -: not expressed; bolt: data from this study; Figures: References. 


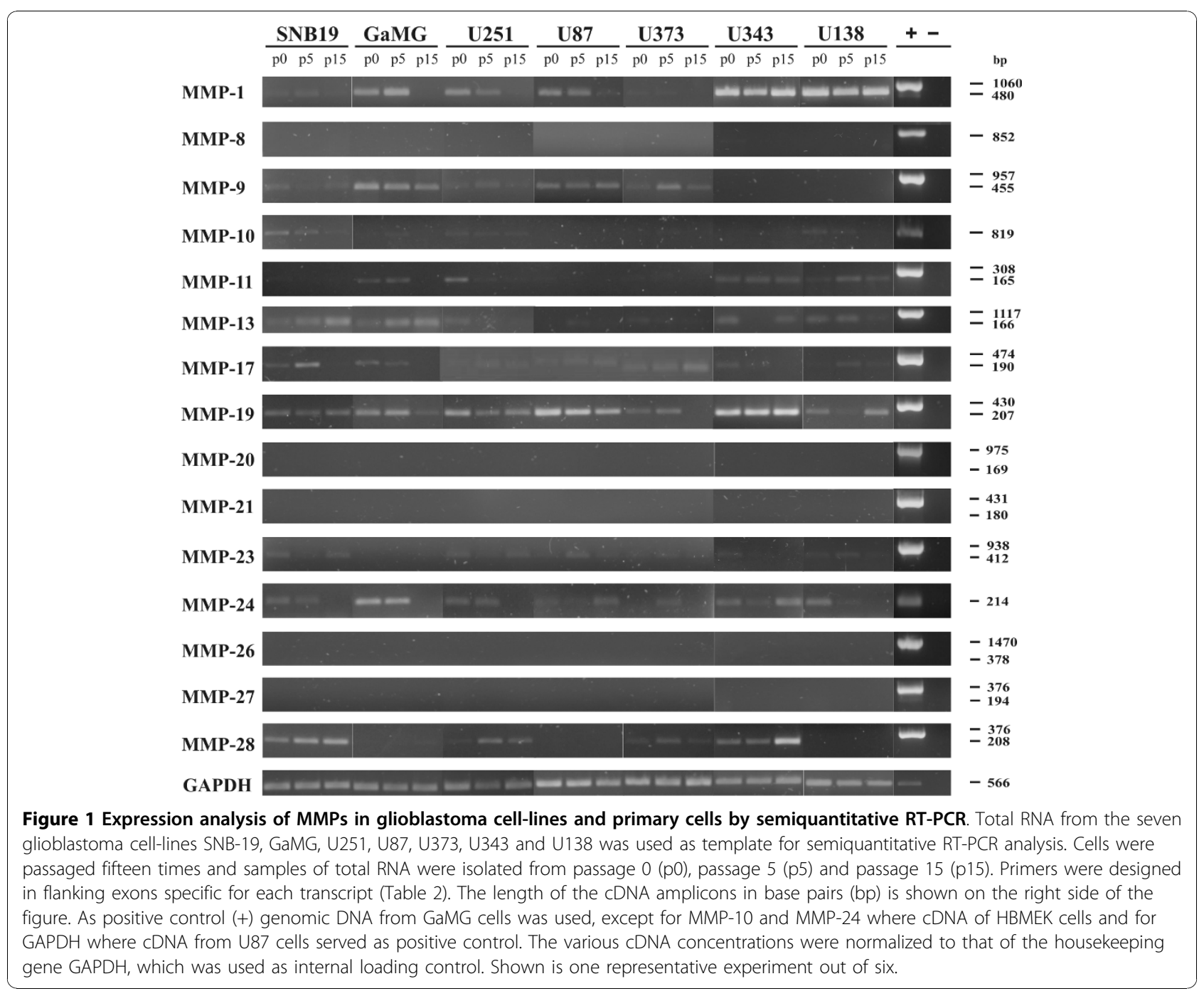

MMP-23 not in GaMG cells and MMP-28 not in U87 cells (Figure 2). An increase of MMP expression was visible at passage 5 in U373 cells for MMP-9 and in GaMG cells for MMP-11, MMP-19 and MMP-24 (Figure 2). This increase was reduced again with further duration of culture (Figure 2). The other MMPs were expressed in varying amounts in the different cell-lines and their expression remained stable over the passages tested (Figure 2).

\section{Expression of MMPs in primary glioblastoma cells}

In addition to the cell-lines, four primary GBM cell cutures, which were derived from patient's tumor samples [16], were analysed for MMP-1, $-8,-9,-10,-11,-13$, $-17,-19,-23,-24$ and MMP-28 mRNA expression by semiquantitative RT-PCR (Figure 3). Very faint expression was detectable for MMP-8, -10, -13 and MMP-28 (Figure 3). Strongest expression could be found for MMP-1, -11 and MMP-19 in the four primary cells (Figure 3). MMP-17, -23 and MMP-24 showed intermediate expression (Figure 3). MMP-9 was strongly expressed in passage 1 of the primary cells, but its expression successively decreased and almost disappeared at passage 10 (Figure 3). Similar data were obtained for MMP-1, MMP-17 and MMP-24, with exception that the latter was expressed constantly in 2262 cells for the investigated 10 passages (Figure 3 ). Whereas MMP-23 expression remained unchanged in the primary cells 2262, 2487 and 2369, its expression was reduced with duration of cell culture in 2423 cells (Figure 3). 2423 cells also were distinctive in MMP-11 expression, since it was increased with advancing passages (Figure 3).

\section{Stimulation of MMP expression by TNF- $\alpha$ and TGF- $\beta 1$ in U251 and U373 cells}

The data presented above indicate that there is a large variety in the MMP expression patterns between different cell-lines and primary cells and that these expression patterns even change with the duration of cell culture. Therefore, we tested whether GBM cell-lines also may be 


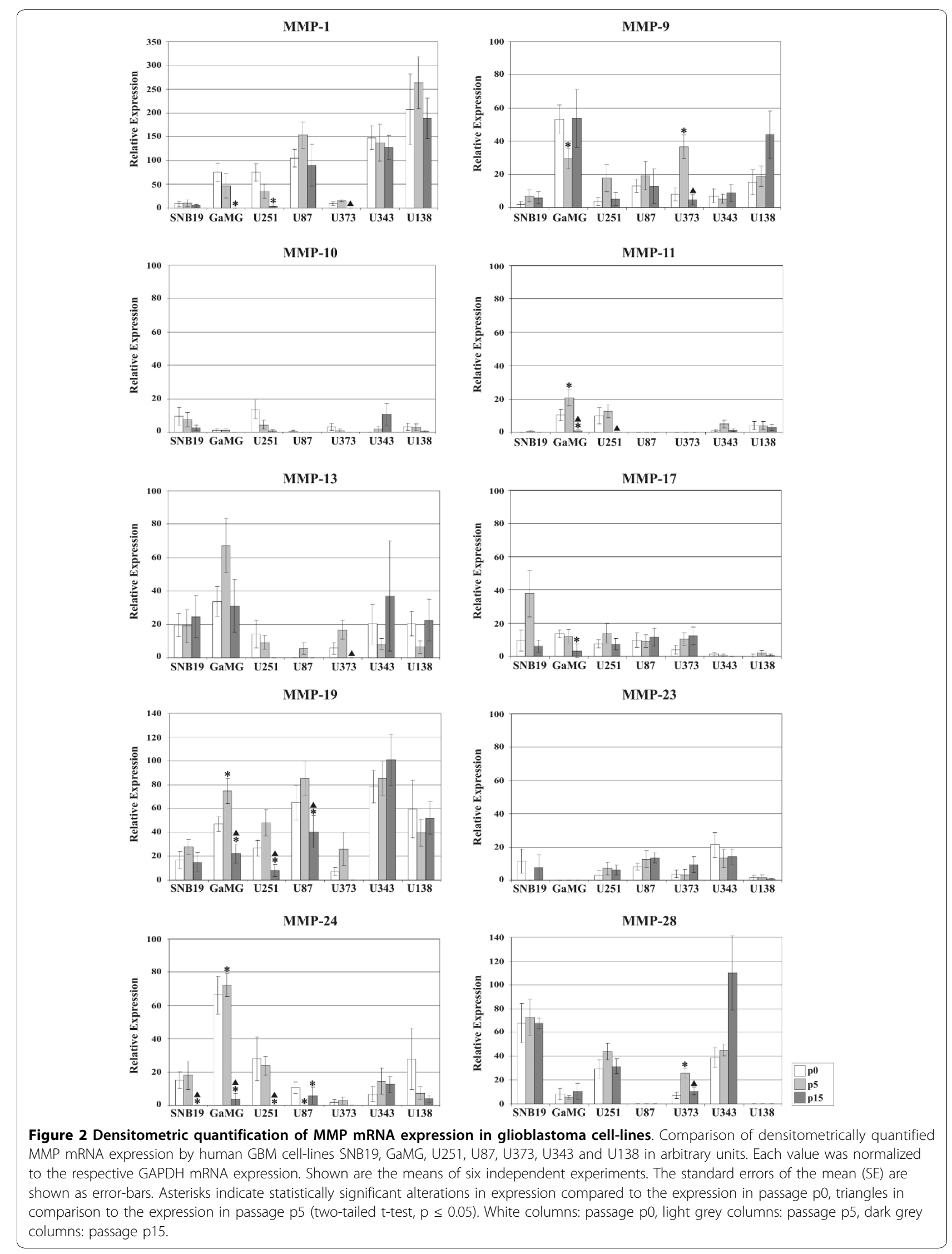




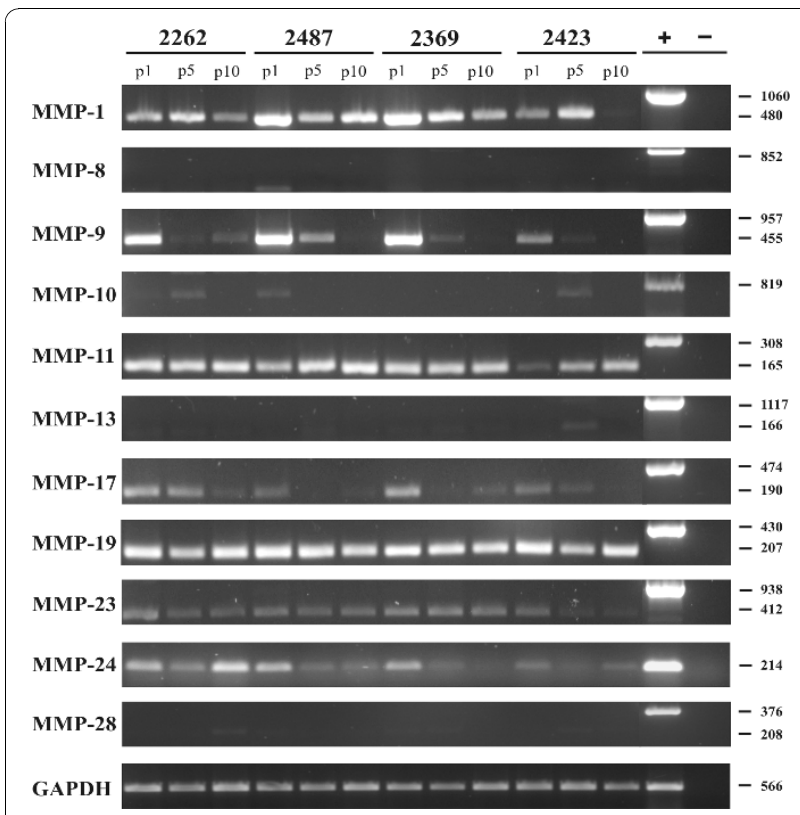

Figure 3 Expression analysis of MMPs in primary glioblastoma cells by semiquantitative RT-PCR. Four different primary cell cultures, derived from patients biopsies, were passaged ten times. Total RNA was isolated from passage 1 (p1), passage 5 (p5) and passage 10 (p10) and used for MMP specific semiquantitative RT$P C R$, as described in Figure 1.

different in their ability to regulate MMP expression after stimulation with cytokines like TNF- $\alpha$ or TGF- $\beta 1$. U251 and U373 GBM cells were successively adjusted to grow in medium without FCS to avoid artefacts by starvation shock and then stimulated either with TNF- $\alpha(10 \mathrm{ng} / \mathrm{ml})$ or TGF- $\beta 1$ (10 $\mathrm{ng} / \mathrm{ml})$. Expression of MMP-1, -9, -11, -19 and MMP-24 was determined by semiquantitative RT-PCR (Figure 4). In both cell-lines TNF- $\alpha$ stimulated expression of MMP-9 and MMP-19 (Figure 4). MMP-1 mRNA expression was significantly increased in U373 cells by TNF- $\alpha$ stimulation, whereas MMP-1 expression in U251 cells remained unaffected (Figure 4). TGF- $\beta 1$ had no impact on MMP expression in U251 cells. However, in U373 cells MMP-11 and MMP-24 expression was significantly increased (Figure 4).

Together these data suggest that not only is the expression pattern of MMPs different in the analysed GBM cell-lines and primary cells, but that also regulation of MMP expression by cytokines diverges.

\section{Discussion}

Active migration of cells and invasion of the tumor into the surrounding normal brain tissue are key features of glioblastomas [2,3]. It has been shown that MMP-9, MMP-2 and its activator MMP-14 are involved in these processes [37-40]. Therefore, these MMPs have been extensively studied in several glioblastoma cell-lines
(Table 1 and references stated there) and first clinical trials are performed for treatment of GBM patients by inhibition of MMPs [41]. However, data about expression of other MMPs in these cells are limited (Table 1). The only comprehensive study is an analysis of U251 cells by quantitative real time PCR for expression of all known 23 human MMPs [31].

Since it has been reported that there are differences in the expression patterns of MMPs in different cell-lines, even if they originate from the same type of tissue [42], we analysed 7 glioblastoma cell-lines (SNB-19, GaMG, U251, U87, U373, U343 and U138) for expression of 15 MMPs (MMP-1, -8, -9, -10, -11, -13, -17, -19, -20, -21, $-23,-24,-26,-27,-28)$ by semiquantitative RT-PCR. For expression of the remaining MMPs in most of the analyzed cell-lines there are already data available in the literature. These literature-data and our own results are summarized in Table 1.

It is conspicuous that MMP-13, $-17,-19$ and -24 were expressed by all analyzed cell-lines, whereas MMP-20 and MMP-21 were not expressed by any of the GBM cells (Table 1, Figure 1, Figure 2). We also did not detect any expression of MMP-8, -26 and -27 in any of the cells examined, whereas Nuttall et al. reported detection of mRNA of these MMPs in U251 cells by quantitative real time PCR [31]. This discrepancy may be due to a higher sensitivity of real time PCR in comparison to our semiquantitative approach. However, our results for MMP-8 and MMP-26 in U251 cells match to those obtained by other groups [26,27]. Chernov et al. performed genome-wide transcripitional profiling and quantitative reverse transcription-PCR of U251 cells [26]. Whereas they found expression of MMP-2, -7, -10, $-13,-15$, and -16 , they did not detect MMP-8 expression [26] and Deng et al. were choosing U251 cells for their MMP-26 overexpression experiments, because these cells did not originally display MMP-26 expression [27].

Controversial data about MMP expression have also been reported for MMP-2 in U251, MMP-3 in U87, U373 and U138, MMP-7 in U87 and U138, MMP-9 in SNB-19, U251, U87 and U373, MMP-11 in U251, MMP-12 in U251 and U138, MMP-14 and -15 in U87 and U373 and MMP-16 in U251 cells (Table 1). For detection of these MMPs such diverse methods as semiquantitative RT-PCR $[19,27,36]$, quantitative real timePCR [26,31,34], gelatin zymography $[10,19,20,25$, $29,30,32,33,36]$, Northern-blotting [10,15,20,29,32], Western-blotting $[10,20,29,30,32,34,36],{ }^{125}$ I Westernblotting after protein concentration [33] and RNase protection assay [28] have been used. This list implies that different methods may come to dissimilar conclusions, due to disparate sensitivities and due to comparing mRNA expression with protein expression or protein activity. However, in most cases these studies coincide 


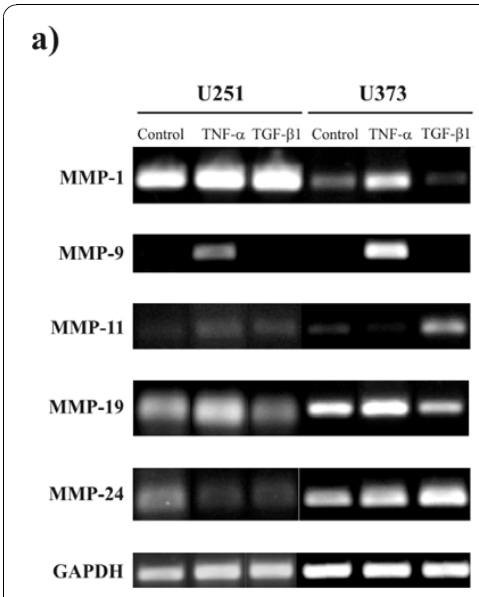

b)

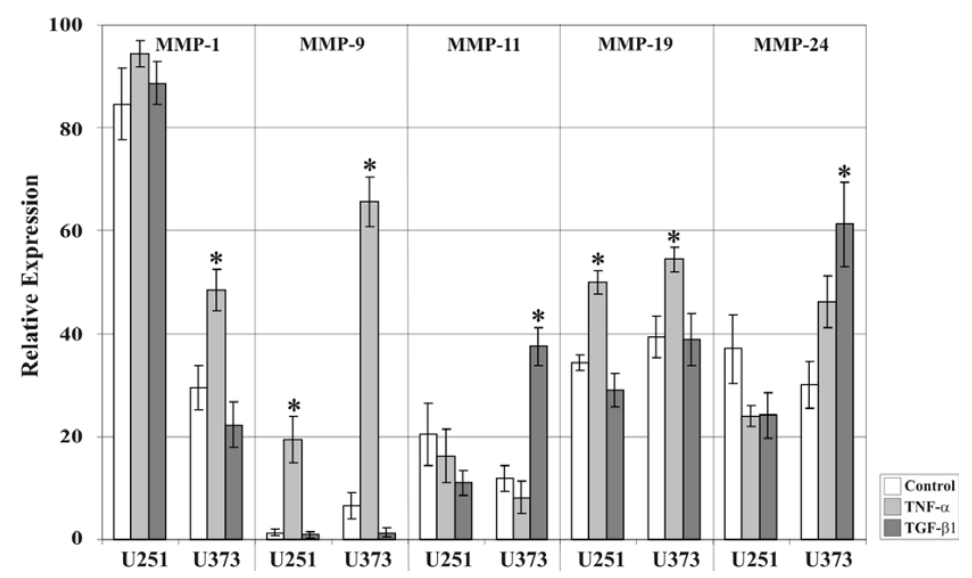

Figure 4 Regulation of MMP mRNA expression by TNF- $\boldsymbol{\alpha}$ and TGF- $\boldsymbol{\beta} 1$. a) U251 and U373 cells were successively adjusted to grow in medium without FCS and stimulated with $10 \mathrm{ng} / \mathrm{ml}$ TNF- $\alpha$ and TGF- $\beta 1$ for $48 \mathrm{~h}$, respectively. Control cells were treated with PBS/BSA solution instead. Total RNA was isolated from these cells and MMP expression strength analysed as explained in Figure 1. Shown is one representative experiment out of six. b) Densitometric quantification of MMP mRNA regulation by TNF- $\alpha$ (light grey columns) and TGF- $\beta 1$ (dark grey columns), respectively, from the above experiment in arbitrary units. Each value was normalized to the respective GAPDH mRNA expression. Shown are the means of six independent experiments. The standard errors of the mean (SE) are shown as error-bars. Asterisks indicate statistically significant (two-tailed t-test, $p \leq 0.05$ ) alterations compared to the untreated control (white columns).

in their results, as can be seen in Table 1 for expression of most MMPs in U251, U87 and U373 cells, suggesting that divergent data may also be caused by other factors. Indeed, we saw fluctuations in MMP-1, $-9,-11,-17,-19$ and MMP-24 mRNA expression with increasing passages in some GBM cell-lines (Figure 1; Figure 2).

MMPs are highly regulated on the transcriptional and also the protein level $[35,38,39]$ and variations in MMP expression, dependent on the number of passages in cell cultures, have been reported [43]. It was suggested that these variations in MMP expression may be due to in vitro selection processes or karyotype evolution where the transcription of either the enzyme and/or its inhibitor may be affected and thus lead to an imbalance in the MMP-regulatory network [43]. However, alterations of MMP expression may also depend on the cells environment. MMP-2, -9 and MMP-14 are differentially upregulated by increasing cellular density [44]. MMP-14 expression also was enhanced if U87 cells were cultured as neurospheres instead as monolayers [45]. Compared

Table 2 Primers and conditions used for semiquantitative RT-PCR screening

\begin{tabular}{|c|c|c|c|c|c|c|}
\hline Gene & Forward primer & Reverse primer & $\operatorname{Tm}\left({ }^{\circ} \mathrm{C}\right)$ & Cycles & cDNA fragment size (bp) & Genomic DNA (bp) \\
\hline MMP-1 & 5'-AAGGCCAGTATGCACAGCTT-3' & 5'-TGCTTGACCCTCAGAGACCT-3' & 57 & 32 & 480 & 1.060 \\
\hline MMP-8 & 5'-TCTGCAAGGTTATCCCAAGG-3' & 5'- ACCTGGCTCCATGAATTGTC-3' & 57 & 32 & 154 & 852 \\
\hline MMP-9 & 5'-CCTGCCAGTTTCCATTCATC-3' & 5'-GCCATTCACGTCGTCCTTAT-3' & 58 & 32 & 455 & 957 \\
\hline MMP-10 & 5'-CCAGTCTGCTCTGCCTATCC-3' & 5'- CATCTCAGATCCCGAAGGAA-3' & 55 & 32 & 819 & 4.199 \\
\hline MMP-11 & 5'-GGGGATGTCCACTTCGACTA-3' & 5'-CAGTGGGTAGCGAAAGGTGT-3' & 50 & 32 & 165 & 308 \\
\hline MMP-13 & 5'-AACATCCAAAAACGCCAGAC-3' & 5'-GGAAGTTCTGGCCAAAATGA-3' & 57 & 32 & 166 & 1.117 \\
\hline MMP-17 & 5'-GGAGCTGTCTAAGGCCATCA-3' & 5'-CGACAGGTTCCTCTTGTTCC-3' & 56 & 32 & 190 & 474 \\
\hline MMP-19 & 5'-CAGCCTCGTTGTGGCCTAGA-3' & 5'-ACCAGCCTGCACCTCTTGGA-3' & 55 & 32 & 207 & 430 \\
\hline MMP-20 & 5'-CGACAATGCTGAGAAGTGGA-3' & 5'-ATCTITGGGGAGGTGGAATC-3' & 57 & 32 & 169 & 975 \\
\hline MMP-21 & 5'-GACGACGACGAGCACTTCAC-3' & 5'-TTTCCTGTCTGACCAGTCCA-3' & 53 & 32 & 180 & 431 \\
\hline MMP-23 & 5'-TGGGACCACTTCAACCTCAC-3' & 5'-CGTGTTGTGAGTGCATCAGG-3' & 55 & 32 & 412 & 938 \\
\hline MMP-24 & 5'-GAACCTGTGGGCAAGACCTA-3' & 5'-TGACAACCAGAAACTGAGCG-3' & 52 & 32 & 214 & 2.650 \\
\hline MMP-26 & 5'-GATATGAAGCCATCCGCAGT-3' & 5'-GCTGGAAGGTTCTAGGGTCG-3' & 58 & 32 & 378 & 1.470 \\
\hline MMP-27 & 5'-TTGTTCTTGTGGCTGCTCA-3' & 5'-GCTAAGCCAAAGGAACCCAC-3' & 53 & 32 & 194 & 376 \\
\hline MMP-28 & 5'-CACCTCCACTCGATTCAGCG-3' & 5'-AAAGCGTTTCTTACGCCTCA-3' & 57 & 32 & 208 & 376 \\
\hline GAPDH & 5'-GCAGGGGGGAGCCAAAAGGG-3' & 5'-TGCCAGCCCCAGCGTCAAAG-3' & 68 & 21 & 566 & 851 \\
\hline
\end{tabular}

$\mathrm{Tm}$ : annealing temperature, bp: base pairs. 
to its expression in U251 cells growing in two-dimensional matrix, MMP-12 expression increased during growth in a three-dimensional Tenascin- $C$ matrix [46]. U87 cells displayed low MMP-7 expression in culture, which was much higher after implantation of the cells within the brain of RAG $2 / \gamma \mathrm{c}$ immune-deficient mice [47], suggesting that the astrocyte environment may influence MMP expression. Astrocytes in culture produce significant amounts of pro-MMP-2, but undetectable levels of active MMP-2. Co-cultured U251 cells are then able to convert pro-MMP-2 into its active form [48]. Therefore, we wondered if primary cells derived from tumor biopsies from patients will change their MMP expression pattern (Figure 3). We analysed tumor samples of GBM-patients by semiquantitative RT-PCR [16] (and unpublished results). From four of these tumors we isolated and cultured primary cells and analysed them at passage 1 , passage 5 and passage 10 (Figure 3). Already passage 1 showed a completely altered MMP expression pattern as seen in the corresponding tumor tissue and this pattern was not stable, but changed with further passages (Figure 3). The pattern was similar to the one seen in established GBM cell-lines, although there were also differences. MMP-1, -11, -17, -23 and MMP-24 expression was stronger in the primary cells. MMP-9 expression showed more alterations during passages in primary cells, but was more stably expressed in the cell-lines. MMP-13 and MMP-28 expression was nearly absent in primary cells, whereas it clearly was visible in the celllines (Figure 1).

Together these data indicate that there is a large variety in the MMP expression patterns between different celllines and primary cells and that these expression patterns are changeable with duration of cell culture and are highly dependent of cell culture conditions and cell-density. Most importantly, these expression patterns do not match to those seen in GBM tumor tissue of patients.

In vivo MMPs are regulated by the surrounding tissue and by growth-factors or cytokines [35,38,39]. Glioblastomas are highly hypoxic and hypoxia upregulates MMP-2 mRNA expression in U87, U251, U373 and LN18 glioblastoma cell-lines by activation of the HIF-1 transcription factor, thereby enhancing their invasive potential [49]. Migration and invasion of U87 and T98G GBM cells is also facilitated by NO, which can be found in high concentrations in glioblastoma tissue [50]. NO stimulates MMP-1 expression and activity [50]. Epidermal growth factor (EGF) raises MMP-14 expression in U251 cells, but does not influence MMP-15, -16 or MMP-24 [34]. MMP-2 expression and secretion is induced by IL- 6 in U87 cells [51]. However, IL-6 action seems to be cell-line specific, since U343 cells were not affected [51]. We analysed the effect of tumor necrosis factor- $\alpha$ (TNF- $\alpha$ ) and transforming growth factor- $\beta 1$ (TGF- $\beta 1$ ) on MMP- $1,-9,-11$,
-19 and MMP-24 expression in U251 and U373 cells (Figure 4). TNF- $\alpha$ and TGF- $\beta 1$ are inflammatory and immunsuppressive cytokines, respectively. They have been implicated in migration and invasion of glioma cells in vitro [52-54]. However, it seems that they have converse impact [52]. In U251 and in U373 cells TNF- $\alpha$ stimulated expression of MMP-9 and MMP-19 (Figure 4). MMP-1 mRNA expression was significantly increased in U373 cells by this cytokine, whereas its expression in U251 cells remained unaffected (Figure 4). This may be due to the high basal level of MMP-1 expression displayed by U251 cells, which does not allow a further increase, or it may be a cell-line specific effect. Such an effect has been observed for MMP-1, $-2,-3$ and MMP-7 regulation by TNF- $\alpha$ and TGF- $\beta 1$, which caused marked induction of expression only in some GBM cell-lines, but not in others [15]. TNF$\alpha$ enhances invasivenes of T98G cells through MMP-3 induction, but has no effect on MMP-1, -2 or MMP-9 expression [55]. However, in U251 cells TNF- $\alpha$ inhibits MMP-2 expression and decreases invasiveness through an extracellular matrix [56]. In A172 cells TNF- $\alpha$ induces gene expression and protein secretion of MMP-9 [57]. TGF- $\beta 1$ alone had no effect on MMP-9 production. However, when it was added together with TNF- $\alpha$ a significant dose-dependent inhibition of MMP-9 secretion was observed [57]. TGF- $\beta 1$ displayed inconsistent effects on adhesion and invasiveness, depending on the cell-line examined. The invasive potential of U138 cells was markedly reduced whereas U373 cell invasion remained unchanged [58]. TGF- $\beta 1$ caused significant induction of MMP-11 and MMP-24 expression in U373 cells, whereas we did not find any impact on MMP expression in U251 cells (Figure 4). In U87 and LN229 cells TGF- $\beta 1$ upregulates MMP-2 [53,54]. Thus, the transcriptional modulation of MMP genes in response to TNF- $\alpha$ or TGF- $\beta 1$ is not consistent, but highly cell-line specific [15].

\section{Conclusions}

Data from literature and our own results suggest that not only is the expression pattern of MMPs highly variable, dependent on the cell-line and the culture-conditions used, but also regulation of MMP expression by cytokines diverges. This is of high impact, if results from cell-culture experiments will be brought forward to the situation in tumor tissue or even will be commuted to clinical applications.

\section{Methods}

\section{Cell-lines and cell culture}

Expression of MMPs was investigated in seven human GBM cell-lines and in four GBM primary cell cultures, which were prepared from GBM tissue samples of patients as described previously [19]. SNB-19, U251, U87, U373, U343 and U138 were originally purchased 
from ATCC (American Type Culture Collection, Rockville, MD) [23]. GaMG cells were established from a patient by the Gade Institute of the University Bergen, Norway [59].

Primary cells and cell-lines were cultured in Dulbecco's modified Eagle's medium (DMEM) (CytoGen, Sinn, Germany) supplemented with $10 \%$ fetal bovine serum (FCS), $4 \times$ nonessential amino acids, $3 \mathrm{mM} \mathrm{L}$-Glutamine, Penicillin $(100 \mathrm{U} / \mathrm{ml})$ and Streptomycin $(100 \mathrm{mg} / \mathrm{ml})$ (all from Invitrogen, Carlsbad, USA). Cells were grown as monolayer in $75 \mathrm{~cm}^{2}$ flasks (Corning, New York, USA) at $37^{\circ} \mathrm{C}$ in a humidified atmosphere containing $5 \% \mathrm{CO}_{2}$. Primary cells were grown from passage number 1 to 10 and cell-lines were passaged 15 times (starting passage was determined as passage 0 ).

\section{Stimulation of cells with TNF- $\alpha$ and TGF- $\beta 1$}

The FCS concentration in the culture medium of U251 and U373 cells was successively reduced from $10 \%$ via $5 \%$ and $2.5 \%$ to $0 \%$ to adjust the cells to grow in medium without FCS. Once cells reached $70 \%$ confluency human recombinant TNF- $\alpha(10 \mathrm{ng} / \mathrm{ml})$ or TGF- $\beta 1$ $(10 \mathrm{ng} / \mathrm{ml})$ (both from Sigma-Aldrich, St. Louis, USA) was added for $48 \mathrm{~h}$ [60]. Control cells were treated with PBS containing $2 \mathrm{mg} / \mathrm{ml}$ BSA.

\section{RNA extraction and semiquantitative RT-PCR}

Total RNA was isolated from the GBM cells using the Nucleo-Spin RNA/Protein Kit (Macherey-Nagel, Düren, Germany) following the manufacturer's protocol. During RNA extraction contaminating genomic DNA was digested with the provided DNase I, as suggested by the manufacturer. Total RNA was eluted in a maximum volume of $60 \mu \mathrm{l}$ RNase-free water and purified samples stored at $-80^{\circ} \mathrm{C}$.

The mRNA expression level of MMPs was evaluated by semiquantitative RT-PCR. Total RNA (1-5 $\mu \mathrm{g})$ was reverse-transcribed using the RevertAid $\mathrm{H}$ minus first strand cDNA synthesis kit (Fermentas, Ontario, Canada) and the provided oligo $(\mathrm{dT})_{18}$ primer. First-strand cDNA synthesis was carried out at $42^{\circ} \mathrm{C}$ for $60 \mathrm{~min}$ in a final reaction volume of $20 \mu \mathrm{l}$ and synthesized cDNA stored at $-20^{\circ} \mathrm{C}$. The amount of cDNA was normalized to the intensity of the PCR product of the ubiquitously expressed gene glyceraldehyde-3-phosphate dehydrogenase (GAPDH) which was used as internal control [61]. Polymerase chain reactions were carried out on the Thermocycler T3 (Biometra, Göttingen, Germany). All primer sequences and PCR conditions are listed in Table 2. Template DNA was mixed with $2.5 \mathrm{U}$ Taq polymerase, $10 \times$ Buffer with $1.5 \mathrm{mM} \mathrm{MgCl} 2$ (Eppendorf, Hamburg, Germany), $200 \mu \mathrm{M}$ dNTPs (Fermentas, St. Leon Rot, Germany), $0.4 \mu \mathrm{M}$ of both, forward and reverse primers (Table 2) and formamide (used optionally at a final concentration of 4\%) in a total reaction volume of $25 \mu \mathrm{l}$. PCR was performed as follows: $5 \mathrm{~min}$ at $94^{\circ} \mathrm{C} ; 21-32$ cycles (Table 2) of $30 \mathrm{sec}$ at $94^{\circ} \mathrm{C}, 30 \mathrm{sec}$ at the optimised annealing temperature (Table 2), $30 \mathrm{sec}$ at $72^{\circ} \mathrm{C}$; followed by a termination step of $10 \mathrm{~min}$ at $72^{\circ} \mathrm{C}$. PCR products were separated on $1 \%$ agarose gels (Sigma-Aldrich, Steinheim, Germany) containing $0.07 \mu \mathrm{g} / \mathrm{ml}$ ethidium-bromide (Roth, Karlsruhe, Germany).

\section{Densitometric quantification and statistical analysis}

The intensity of ethidium bromide fluorescence was densitometrically analyzed using the BioDocAnalyze software (Biometra, Göttingen, Germany). The DNA bands were normalized to the respective fragment intensity of the housekeeping gene GAPDH. Statistical analysis was performed using Microsoft Office Excel 2003 (Microsoft Deutschland, Unterschleißheim, Germany). Values were expressed as means \pm standard error of the mean (SE). Statistical significance was defined by two tailed $\mathrm{t}$-tests and $\mathrm{p} \leq 0.05$ was considered to be significant.

\section{Acknowledgements}

We are grateful to Stefanie Gerngras, Siglinde Kühnel and Renate Bausch for technical assistance. This project was financially supported by

"Interdisziplinäres Zentrum für Klinische Forschung der Universität Würzburg (IZKF)", B-25.

\section{Author details}

'University of Würzburg, Department of Neurosurgery, Tumorbiology Laboratory, Würzburg, Germany. ${ }^{2}$ Department of Gynaecology and Obstetrics, University of Würzburg, Würzburg, Germany. ${ }^{3}$ Department of Internal Medicine I, Laboratory of Experimental Rheumatology and Neuroendocrino-Immunology, University of Regensburg, Regensburg, Germany.

\section{Authors' contributions}

$\mathrm{CH}$ and JA contributed equally as primary authors of the manuscript. They designed and supervised the study. SH performed the semiquantitative RTPCRs. DR and BS analysed MMP expression after cytokine stimulation. SH, DR and BS did the statistical analysis and generated figures. RIE and GHV participated in the study design and critically reviewed the manuscript. All authors read and approved the final manuscript.

\section{Competing interests}

The authors declare that they have no competing interests.

Received: 29 September 2010 Accepted: 10 November 2010 Published: 10 November 2010

\section{References}

1. Reifenberger G, Collins VP: Pathology and molecular genetics of astrocytic gliomas. J Mol Med 2004, 82:656-670.

2. Demuth T, Berens ME: Molecular mechanisms of glioma cell migration and invasion. J Neur-Oncol 2004, 70:217-228.

3. Ohgaki H, Dessen P, Jourde B, Horstmann S, Nishikawa T, DiPatre PL, Burkhard C, Schuler D, Probst-Hensch NM, Maiorka PC, Baeza N, Pisani P, Yonekawa Y, Yasargil MG, Lutolf UM, Kleihues P: Genetic pathways to glioblastoma: a population-based study. Cancer Res 2004, 64:6892-6899.

4. Stupp R, Mason WP, van den Bent MJ, Weller M, Fisher B, Taphoorn MJ, Belanger K, Brandes AA, Marosi C, Bogdahn U, Curschmann J, Janzer RC, Ludwin SK, Gorlia T, Allgeier A, Lacombe D, Cairncross JG, Eisenhauer E, Mirimanoff RO, European Organisation for Research and Treatment of 
Cancer Brain Tumor and Radiotherapy Groups, National Cancer Institute of Canada Clinical Trials Group: Radiotherpay plus concomitant and adjuvant temozolomide for glioblastoma. N Engl J Med 2005, 352:987-996.

5. Fillmore HL, VanMeter TE, Broaddus WC: Membrane-type matrix metalloproteinases (MT-MMPs): expression and function during glioma invasion. J Neuro-Oncol 2001, 53:187-202.

6. Velasco G, Cal S, Merlos-Suarez A, Ferrando AA, Alvarez S, Nakano A Arribas J, Lopez-Otin C: Human MT6-matrix metalloproteinase: identification, progelatinase $\mathrm{A}$ activation, and expression in brain tumors. Cancer Res 2000, 60:877-882.

7. Egeblad M, Werb Z: New functions for the matrix metalloproteinases in cancer progression. Nat Rev Cancer 2002, 2:161-174.

8. Nagase H, Visse R, Murphy G: Structure and function of matrix metalloproteinases and TIMPs. Cardiovasc Res 2006, 69:562-573.

9. Forsyth PA, Dickinson-Laing T, Gibson AW, Rewcastle NB, Brasher P, Sutherland G, Johnston RN, Edwards DR: High levels of gelatinase-B and active gelatinase-A in metastatic glioblastoma. J Neuro-Oncol 1998, 36:21-29.

10. Hur JH, Park MJ, Park IC, Yi DH, Rhee CH, Hong SI, Lee SH: Matrix metalloproteinases in human gliomas: activation of matrix metalloproteinase-2 (MMP-2) may be correlated with membrane-type-1 matrix metalloproteinase (MT1-MMP) expression. J Korean Med Sci 2000, 15:309-314.

11. Lampert K, Machein U, Machein MR, Conca W, Peter HH, Volk B: Expression of matrix metalloproteinases and their tissue inhibitors in human brain tumors. Am J Pathol 1998, 153:429-437.

12. Llano E, Pendas AM, Freije JP, Nakano A, Knauper V, Murphy G, LopezOtin C: Identification and characterization of human MT5-MMP, a new membrane-bound activator of progelatinase $A$ overexpressed in brain tumors. Cancer Res 1999, 59:2570-2576.

13. Nakada M, Nakamura $H$, Ikeda E, Fujimoto $N$, Yamashita J, Sato H, Seiki M, Okada Y: Expression and tissue localization of membrane-type 1, 2, and 3 matrix metalloproteinases in human astrocytic tumors. Am J Pathol 1999, 154:417-428

14. Nakagawa T, Kubota T, Kabuto M, Sato K, Kawano H, Hayakawa T, Okada Y: Production of matrix metalloproteinases and tissue inhibitor of metalloproteinases-1 by human brain tumors. J Neurosurg 1994, 81:69-77.

15. Nakano A, Tani E, Miyazaki K, Yamamoto Y, Furuyama J: Matrix metalloproteinases and tissue inhibitors of metalloproteinases in human gliomas. J Neurosurg 1995, 83:298-307.

16. Stojic J, Hagemann C, Haas S, Herbold C, Kühnel S, Gerngras S, Roggendorf W, Roosen K, Vince GH: Expression of matrix metalloproteinases MMP-1, MMP-11 and MMP-19 is correlated with the WHO-grading of human malignant gliomas. Neurosci Res 2008, 60:40-49.

17. Tonn JC, Kerkau S, Hanke A, Bouterfa H, Mueller JG, Wagner S, Vince GH, Roosen K: Effect of synthetic matrix-metalloproteinase inhibitors on invasive capacity and proliferation of human malignant gliomas in vitro. Int J Cancer 1999, 80:764-772.

18. Vince GH, Wagner S, Pietsch T, Klein R, Goldbrunner RH, Roosen K, Tonn JC: Heterogeneous regional expression patterns of matrix metalloproteinases in human malignant gliomas. Int J Dev Neurosci 1999, 17:437-445.

19. Wagner S, Stegen C, Bouterfa H, Huettner C, Kerkau S, Roggendorf W, Roosen K, Tonn JC: Expression of matrix metalloproteinases in human glioma cell lines in the presence of IL-10. J Neurooncol 1998, 40:113-122.

20. Yamamoto M, Mohanam S, Sawaya R, Fuller GN, Seiki M, Sato $H$, Gokaslan ZL, Liotta LA, Nicolson GL, Rao JS: Differential expression of membrane-type matrix metalloproteinase and its correlation with gelatinase A activation in human malignant brain tumors in vivo and in vitro. Cancer Res 1996, 56:384-392.

21. Engebraaten O, Bjerkvig R, Berens ME: Effect of alkyl-lysophospholipid on glioblastoma cell invasion into fetal rat brain tissue in vitro. Cancer Res 1991, 51:1713-1719.

22. Hagemann C, Gloger J, Anacker J, Said HM, Gerngras S, Kühnel S, Meyer C, Rapp UR, Kämmerer U, Vordermark D, Flentje M, Roosen K, Vince GH: RAF expression in human astrocytic tumors. Int J Mol Med 2009, 23:17-31.

23. Hagemann C, Said HM, Flentje M, Roosen K, Vince GH: Proteins involved in cell migration from glioblastoma neurospheres analyzed by overexpression and siRNA-mediated knock-down. In RNAi and micro RNAmediated gene regulation in stem cells. Methods in Molecular Biology 650.
Edited by: Zhang B, Stellwag EJ. New York, Dordrecht, heidelberg, London: The Humana Press Inc; 2010:129-143.

24. Pilkington GJ, Bjerkvig R, De Ridder L, Kaaijk P: In vitro and in vivo models for the study of brain tumour invasion. Anticancer Res 1997, 17:4107-4109.

25. Abe T, Mori T, Kohno K, Seiki M, Hayakawa T, Welgus HG, Hori S, Kuwano M: Expression of $72 \mathrm{kDa}$ type IV collagenase and invasion activity of human glioma cells. Clin Exp Metastasis 1994, 12:296-304.

26. Chernov AV, Baranovskaya S, Golubkov VS, Wakeman DR, Snyder EY, Williams R, Strongin AY: Microarray-based transcriptional and epigenetic profiling of matrix metalloproteinases, collagens, and related genes in cancer. J Biol Chem 2010, 285:19647-19659.

27. Deng Y, Li W, Yang H, Xu H, Liang S, Zhang L, Li Y: Expression of matrix metalloproteinase-26 promotes human glioma U251 cell invasion in vitro and in vivo. Oncol Rep 2010, 23:69-78.

28. Kim SY, Jung SH, Kim HS: Curcumin is a potent broad spectrum inhibitor of matrix metalloproteinase gene expression in human astroglioma cells. Biochem and Biophys Res Comm 2005, 337:510-516.

29. Kondraganti S, Mohanam S, Chintala SK, Kin Y, Jasti SL, Nirmala C, Lakka SS, Adachi Y, Kyritsis AP, Ali-Osman F, Sawaya R, Fuller GN, Rao JS: Selective suppression of matrix metalloproteinase- 9 in human glioblastoma cells by antisense gene transfer impairs glioblastoma cell invasion. Cancer Res 2000, 60:6851-6855.

30. Lakka SS, Gondi CS, Yanamandra N, Olivero WC, Dinh DH, Gujrati M, Rao JS: Inhibition of cathepsin B and MMP-9 gene expression in glioblastoma cell-line via RNA interference reduces tumor cell invasion, tumor growth and angiogenesis. Oncogene 2004, 23:4681-4689.

31. Nuttall RK, Pennington CJ, Taplin J, Wheal A, Yong WW, Forsyth PA, Edwards DR: Elevated membrane-type matrix metalloproteinases in gliomas revealed by profiling proteases and inhibitors in human cancer cells. Mol Cancer Res 2003, 1:333-345.

32. Shofuda Ki, Moriyama K, Nishihashi A, Higashi S, Mizushima H, Yasumitsu H, Miki K, Sato H, Seiki M, Miyazaki K: Role of tissue inhibitor of metalloproteinases-2 (TIMP-2) in regulation of pro-gelatinase $A$ activation catalyzed by membrane-type matrix metalloproteinase-1 (MT1-MMP) in human cancer cells. J Biochem 1998, 124:462-470.

33. Uhm JH, Dooley NP, Villemure JG, Yong WW: Glioma invasion in vitro: regulation by matrix metalloproteinase- 2 and protein kinase C. Clin Exp Metastasis 1996, 14:421-433.

34. Van Meter TE, Broaddus WC, Rooprai HK, Pilkington GJ, Fillmore HL: Induction of membrane-type-1 matrix metalloproteinase by epidermal growth factor-mediated signaling in gliomas. Neuro-Oncol 2004, 6:188-199.

35. Van Meter TE, Rooprai HK, Kibble MM, Fillmore HL, Broaddus WC, Pilkington GJ: The role of matrix metalloproteinase genes in glioma invasion: co-dependent and interactive proteolysis. J Neurooncol 2001 53:213-235.

36. Wild-Bode C, Weller M, Wick W: Molecular determinants of glioma cell migration and invasion. J Neurosurg 2001, 94:978-984.

37. Kargiotis O, Chetty C, Gondi CS, Tsung AJ, Dinh DH, Gujrati M, Lakka SS, Kyritsis AP, Rao JS: Adenovirus-mediated transfer of siRNA against MMP-2 mRNA results in impaired invasion and tumor-induced angiogenesis, induces apoptosis in vitro and inhibits tumor growth in vivo in glioblastoma. Oncogene 2008, 27:4830-4840.

38. Lakka SS, Gondi CS, Rao JS: Proteases and glioma angiogenesis. Brain Pathol 2005, 15:327-341.

39. Levicar N, Nutall RK, Lah TT: Proteases in brain tumour progression. Acta Neurochir 2003, 145:825-838.

40. Nakada M, Okada Y, Yamashita J: The role of matrix metalloproteinases in glioma invasion. Front Biosci 2003, 8:e261-e269.

41. Gabelloni P, Da Pozzo E, Bendinelli S, Costa B, Nuti E, Casalini F, Orlandini E, Da Settimo F, Rossello A, Martini C: Inhibition of metalloproteinases derived from tumors: new insights in the treatment of human glioblastoma. Neurosci 2010, 168:514-522.

42. Giambernardi TA, Grant GM, Taylor GP, Hay RJ, Maher VM, McCormick JJ, Klebe RJ: Overview of matrix metalloproteinase expression in cultured human cells. Matrix Biol 1998, 16:483-496.

43. Rossi M, Rooprai HK, Maidment SL, Rucklidge GJ, Pilkington GJ: The influence of sequential, in vitro passage on secretion of matrix metalloproteinases by human brain-tumor cells. Anticancer Res 1996, 16:121-128. 
44. Trog D, Yeghiazaryan K, Fountoulakis M, Friedlein A, Moenkemann H, Haertel N, Schueller H, Breipohl W, Schild H, Leppert D, Golubnitschaja O: Pro-invasive gene regulating effect of irradiation and combined temozolomide-radiation treatment on surviving human malignant glioma cells. Eur J Pharmacol 2006, 542:8-15.

45. Annabi B, Laflamme C, Sina A, Lachambre MP, Béliveau R: A MT1-MMP/ $\mathrm{NFKB}$ signaling axis as a checkpoint controller of COX-2 expression in CD133(+) U87 glioblastoma cells. J Neuroinflammation 2009, 6:8.

46. Sarkar S, Nuttall RK, Liu S, Edwards DR, Yong WW: Tenascin-C stimulates glioma cell invasion through matrix metalloproteinase-12. Cancer Res 2006, 66:11771-11780.

47. Rome C, Arsaut J, Taris C, Couillaud F, Loiseau H: MMP-7 (Matrilysin) expression in human brain tumors. Mol Carcinogenesis 2007, 46:446-452.

48. Le DM, Besson A, Fogg DK, Choi KS, Waisman DM, Goodyer CG, Rewcastle B, Yong W: Exploitation of astrocytes by glioma cells facilitate invasiveness: a mechanism involving matrix metalloproteinase-2 and the Urokinase-type Plasminogen activator-plasmin cascade. J Neurosci 2003, 23:4034-4043.

49. Fujiwara S, Nakagawa K, Harada H, Nagato S, Furukawa K, Teraoka M, Seno T, Oka K, Iwata S, Ohnishi T: Silencing hypoxia-inducible factor-1a inhibits cell migration and invasion under hypoxic environment in malignant gliomas. Int J Oncol 2007, 30:793-802.

50. Pullen NA, Fillmore HL: Induction of matrix metalloproteinase-1 and glioma cell motility by nitric oxide. J Neurooncol 2010, 96:201-209.

51. Li R, Li G, Deng L, Liu Q, Dai J, Shen J, Zhang J: IL-6 augments the invasivness of U87 human glioblastoma multiforme cells via upregulation of MMP-2 and fascin-1. Oncol Rep 2010, 23:1553-1559.

52. Chicoine MR, Silbergeld DL: Mitogens as motogens. J Neuro-Oncol 1997, 35:249-257.

53. Platten $M$, Wick W, Weller M: Malignant glioma biology: role for TGF- $\beta$ in growth, motility, angiogenesis, and immune escape. Microscopy Res and Technique 2001, 52:401-410

54. Wick W, Platten M, Weller M: Glioma cell invasion: regulation of metalloproteinase activity by TGF- $\beta$. J Neuro-Oncol 2001, 53:177-185.

55. Cheng SM, Xing B, Li JCB, Cheung BKW, Lau ASY: Interferon- $\gamma$ regulation of TNFa-induced matrix metalloproteinase 3 expression and migration of human glioma T98G cells. Int J Cancer 2007, 121:1190-1196.

56. Qin $H$, Moellinger JD, Wells $A$, Windsor $\sqcup$, Sun $Y$, Benveniste EN: Transcriptional suppression of matrix metalloproteinase- 2 gene expression in human astroglioma cells by TNF-a and IFN- $\gamma$. J Immunol 1998, 161:6664-6673.

57. Esteve PO, Tremblay P, Houde M, St-Pierre Y, Mandeville R: In vitro expression of MMP-2 and MMP-9 in glioma cells following exposure to inflammatory mediators. Biochim Biophys Acta 1998, 1403:85-96.

58. Paulus W, Baur I, Huettner C, Schmaußer B, Roggendorf W, Schlingensiepen $\mathrm{H}$, Brysch W: Effects of transforming growth factor-beta1 on collagen synthesis, integrin expression, adhesion and invasion of glioma cells. J Neuropathol Exp Neurol 1995, 54:236-244.

59. Akslen LA, Andersen KJ, Bjerkvig R: Characteristics of human and rat glioma cells grown in a defined medium. Anticancer Res 1988, 8:797-803.

60. Rooprai HK, Rucklidge GJ, Panou C, Pilkington GJ: The effects of exogenous growth factors on matrix metalloproteinase secretion by human brain tumour cells. Brit J Cancer 2000, 82:52-55.

61. Said HM, Hagemann C, Stojic J, Schömig B, Vince GH, Flentje M, Roosen K, Vordermark D: GAPDH is not regulated in human glioblastoma under hypoxic conditions. BMC Molecular Biology 2007, 8:55.

doi:10.1186/1756-0500-3-293

Cite this article as: Hagemann et al:: Comparative expression pattern of Matrix-Metalloproteinases in human glioblastoma cell-lines and primary cultures. BMC Research Notes 2010 3:293.

\section{Submit your next manuscript to BioMed Central and take full advantage of:}

- Convenient online submission

- Thorough peer review

- No space constraints or color figure charges

- Immediate publication on acceptance

- Inclusion in PubMed, CAS, Scopus and Google Scholar

- Research which is freely available for redistribution

Submit your manuscript at www.biomedcentral.com/submit
C Biomed Central 